\title{
Systemic Anaplastic Large Cell Lymphoma
}

National Cancer Institute

\section{Source}

National Cancer Institute. Systemic Anaplastic Large Cell Lymphoma. NCI Thesaurus.

Code C9470.

An anaplastic large cell lymphoma that is not confined to a single anatomic site and involves multiple nodal and/or extranodal sites. 